\title{
Assessment of chlorine resistant bacteria and their susceptibility to antibiotic from water distribution system in Duhok province
}

\author{
Mohammad I. Al-Berfkani1*, Anies I. Zubair¹, Husham Bayazed² \\ ${ }^{1}$ Department of Medical Laboratory Technique, Zakho Technical Institute, Duhok Polytechnic University, Duhok, Iraq \\ ${ }^{2}$ Scientific Research Center, Zakho University, Duhok, Iraq.
}

\begin{tabular}{l} 
ARTICLE INFO \\
\hline Article history: \\
Received on: 20/11/2014 \\
Revised on: 02/12/2014 \\
Accepted on: 18/12/2014 \\
Available online: 27/12/2014 \\
\hline Key words: \\
Chlorination, antibiotic, \\
Resistant, Bacteria.
\end{tabular}

\begin{abstract}
Chlorination has been most widely practiced method of disinfection for potable waters since the turn of century and principal means by which the microbial quality of water is maintained in Iraq. Khabur river is the main source of our drinking water in Zahko-Duhok city, here chlorine in form of hypochlorous at concentration $2 \mathrm{ppm}$ are most used. In this paper we have attempted to compare sensitivity of microorganisms toward chlorine and also we have tried to determination of chlorine resistance bacteria to antibiotics. Results from our experiment suggest that bacteria isolated from post chlorinated water samples are more resistant to chlorine disinfection than prechlorinated water samples. the isolated organisms are Staphylococcus aureus, Micrococcus varians and Aeromonas hydrophila fully resistant to chlorine at this concentration and the most resistant bacterium of all isolates is Staphylococci. Although the strains were sensitive to abroad spectrum of antibiotics but the strains show resistant to the most important clinical antibiotics. Suggestion that either the synthesis of unique proteins or aggregation of the bacteria as mechanisms of resistance to inactivation. This study will help us to suggest relevant changes in purification processes for supply of better quality of drinking water to our Municipal Corporation.
\end{abstract}

\section{INTRODUCTION}

Waterborne diseases are caused by pathogenic microorganisms which are directly transmitted through drinking water which lack adequate sanitation, these diseases can be prevented with appropriate water treatment and proper sanitation. Disinfection by chlorine is important step in drinking water treatment to prevent pathogens breakthrough into water supply systems, Chlorine, the most common disinfectant in Iraq, it is effective in killing most pathogenic bacteria and viruses, it is a strong oxidant that rapidly kills many harmful microorganisms. Because chlorine is a toxic gas, there is a danger of a release associated with its use. In aqueous environments, uncombined chlorine, in the form of unionized hypochlorous acid $(\mathrm{HOCl})$, is an extremely potent bactericidal and virucidal agent, even at concentrations of less than $0.1 \mathrm{mg}$ liter-' [1]. Despite of bactericidal properties of chlorine in the environment are not yet fully understood, Many researches show that large numbers of microorganisms which show to be human opportunistic pathogens can recovered from portable water distribution systems maintaining free chlorine residuals of 0.5 to $1.0 \mathrm{mg} / \mathrm{liter}$ $[2,3]$. Many studies have been demonstrated about occurrence

* Corresponding Author

Mohammad I. Al-Berfkani, Department of Medical Laboratory

Technique, Zakho Technical Institute, Duhok Polytechnic University,

Duhok,Iraq.E-mail: Mohammad.said@dpu.ac of chlorine resistant bacteria in drinking water and wastewater $[4,5,6,7]$ and is considered an important potential health problem. Ridgway and Olson (1982) have shown that the majority of viable bacteria in chlorinated drinking water are attached to particles. Presumably, microbes entrapped in particles or adsorbed onto surfaces are shielded from disinfection and are not inactivated. Similar finding have been reported by Geldreich et al. (1996) that bacteria from chlorinated system were more resistant than those from the un-chlorinated waters [8]. Thus, specific mechanisms may exist for the survival of certain bacteria and viruses in waters containing relatively high concentrations of chlorine $[9,10]$. Bacterial re-growth in distribution systems is linked to the development of a biofilm (i.e., attached growth) on pipe walls. Biofilm development occurs because biodegradable organic material (BOM) and inorganic nutrients are present in finished drinking water. Antibiotic resistant microorganisms in drinking water has been demonstrated in many studies $[11,12,13,14,15$, $16,17]$ which is important in public health, it is important because of the ability of these microorganisms to transmit resistance to other organisms by means of transmissible resistance factors (R-factor) $[18,19,20,21]$. Khaber river is the major source of domestic water supply to Zakho city, Municipal potable water supplies are chlorinated to provide a residual concentration of $1.4 \mathrm{ppm}$. Although, many researchers have done to screening chlorine resistant bacteria from drinking water in the world, but no such research have been in our city even in our country. 
So it is important to determine to what extent chlorine resistant bacteria occur in municipal drinking water supplies. In this research bacterial strains were isolated from an untreated (prechlorinated) water and (Post chlorinated) treated chlorinated water system.

\section{MATERIAL AND METHODS}

\subsection{Collection of samples}

This study was conducted at Zahko technical institute, medical analysis department from May 2013 to May 2014. A total of 100 water samples were randomly collected from khaber treatment and distribution plant, Zahko, Duhok city. The water treatment and distribution plant uses calcium hypochlorite with active chlorine $65 \%$ in the chlorination process with the free residual chlorine of 0.1-0.2 ppm for a contact time of 30 minutes.

The samples were collected aseptically from khaber Water Works. Two types of sample were collected i.e. prechlorinated water sample (raw water which is not treated yet) and post chlorinated water sample (water fully treated and potable). All water samples collected in a sterile bottle containing $3 \%(\mathrm{w} / \mathrm{v})$ sodium thiosulfate solution. The samples were stored on ice and returned to the laboratory (within 4 hours).

\subsection{Microbiological Sampling and Taxonomic Identification}

A portion of water samples added to MacConkey's broth both double strength and single strength which containing peptone- $20 \mathrm{~g}$, bile salt- $5 \mathrm{~g}$, neutral red- $0.06 \mathrm{~g}$ in 1 litre distill water. For double strength, double the ingredients and keep water volume constant. From positive tubes a loopful of suspension was streaked on nutrient agar and incubated at $35^{\circ} \mathrm{C}$ for at which time colonies were enumerated and transferred to nutrient agar for cold storage (4 $\circ$ C) and subsequent taxonomic identification. Total three microorganisms were isolated. Colony morphology and characterization was carried out of each isolate. The cultural and morphologic characterization of isolates was followed by Gram staining, motility, biochemical tests include: catalase, oxidase, indole and methyl red and voges proskaver, citrate utilization , fermentation of carbohydrate (glucose, lactose, Mannitol, sucrose and xylose) and by using Analytic Profile Index System .

\subsection{Determination of in vitro resistance to chlorine}

The bacterial isolates were incubated into disk assay broth containing (per liter of distilled water: $0.5 \mathrm{~g}$ of tryptone, $0.5 \mathrm{~g}$ of yeast extract and $0.5 \mathrm{~g}$ of dextrose) cultures were incubated at $35^{\circ} \mathrm{C}$ for 24 hours so that the young cultures could be in the exponential growth phase. Cultures were then diluted into fresh disk assay broth to barely visible turbidity, this corresponded to an optical density of 0.5 using a $600 \mathrm{~nm}$. This must have $1 \times 10^{\wedge} 6$ to $1 \mathrm{x} 10^{\wedge} 8$ per $\mathrm{ml}$. A stock solution of chlorine was prepared daily from Calcium hypochlorite solution $10 \%$ or $100,000 \mathrm{ppm}$ in distilled sterile water. Dilution of 10000, 5000, 1000, 100, 50, 10, 1 and $0.5 \mathrm{ppm}$ were undertaken from this solution with nutrition broth as diluting medium. Cultures of isolated strains were inoculated in tubes with different concentration of calcium hypochlorite. The cells remained in contact with the substance for 10, 20 and 30 minutes; the cultures were then inoculated in plates with nutrition agar and incubated at $37^{\circ} \mathrm{C}$ for 24 hours. The presence of growth was considered a positive result.

\subsection{Determination of chlorine resistance bacteria to antibiotic}

Resistance strains of bacteria for different antibiotics was determined by the diffusion method, following Bauer et al. (1966). Five antimicrobial agents were chosen as its application in medical clinic practice and because they present different mechanisms with different actions: for inhibition of cell wall synthesis were used Amoxicillin (AM) and Vancomycin (Va) ,while for inhibition of protein synthesis were used Tetracycline (Te) and Clindamycin (DA), and for inhibition of nucleic acid synthesis were used Rifampin (RA).

A single colony of each of strain were incubated into 5 $\mathrm{ml}$ of sterile broth and incubated at $37^{\circ} \mathrm{C}$ for 6 hours to given an concentration $10^{\wedge} 8$ cells per ml. Muller Hinton agar (Difco) plates were seeded by swabbing with cotton moistened with the culture. After the plates were dried for $1 \mathrm{~h}$, antibiotic disks were put in the plate by using semiautomatic dispenser. Diameters of the inhibition zones surrounding the disks were recorded after incubated antiseptically at $37^{\circ} \mathrm{C}$ for 18 hours and then compared with rates of table standards and susceptibility to tested antimicrobials. Bacterial isolates were characterized as resistant or sensitive [22].

Table 1: profile of resistance to chlorine in different concentration at different contact times

\begin{tabular}{|c|c|c|c|c|c|c|c|c|c|c|c|c|c|c|c|c|c|c|}
\hline \multirow{3}{*}{ Strain } & \multicolumn{18}{|c|}{ Concentration (ppm) / Time exposed (min) } \\
\hline & \multicolumn{3}{|c|}{ 1ppm } & \multicolumn{3}{|c|}{10 ppm } & \multicolumn{3}{|c|}{$50 \mathrm{ppm}$} & \multicolumn{3}{|c|}{$100 p p m$} & \multicolumn{3}{|c|}{ 1000ppm } & \multicolumn{3}{|c|}{$5000 p p m$} \\
\hline & 10 & 20 & 30 & 10 & 20 & 30 & 10 & 20 & 30 & 10 & 20 & 30 & 10 & 20 & 30 & 10 & 20 & 30 \\
\hline Staphylococcus aureus & + & + & + & + & + & + & + & + & + & + & + & + & - & - & - & - & - & - \\
\hline Micrococcus varians & + & + & + & + & + & + & + & + & + & + & + & + & - & - & - & - & - & - \\
\hline Aeromonas hydrophila. & + & + & + & + & + & + & + & + & + & + & - & - & - & - & - & - & - & - \\
\hline
\end{tabular}

Note: (+) mean growth of bacteria

(-) mean no growth of bacteria

Table 2: profile of resistance bacteria to antibiotics.

\begin{tabular}{|c|c|c|c|c|c|c|c|c|c|c|c|c|c|c|}
\hline \multirow[t]{2}{*}{ organisms } & \multicolumn{14}{|c|}{ Antibiotic (mm) } \\
\hline & RA & VA & CIP & $\mathbf{E}$ & DA & AK & TE & DO & $\mathbf{L}$ & $\mathbf{C N}$ & $\mathbf{P}$ & $\mathbf{K F}$ & Amc & SXT \\
\hline Staphylococcus aureus & $\mathrm{S}$ & $\mathrm{S}$ & $\mathrm{S}$ & $\mathrm{S}$ & $\mathrm{S}$ & $\mathrm{S}$ & $\mathrm{S}$ & $\mathrm{S}$ & $\mathrm{S}$ & $\mathrm{S}$ & $\mathrm{R}$ & $\mathrm{R}$ & $\mathrm{R}$ & $\mathrm{R}$ \\
\hline Micrococcus varians & $\mathrm{S}$ & $\mathrm{S}$ & $\mathrm{S}$ & S & S & S & $\mathrm{S}$ & S & $\mathrm{S}$ & $\mathrm{S}$ & $\mathrm{R}$ & $\mathrm{R}$ & $\mathrm{R}$ & $\mathrm{R}$ \\
\hline Aeromonas hydrophila. & $\mathrm{S}$ & $\mathrm{S}$ & $\mathrm{S}$ & $\mathrm{S}$ & S & $\mathrm{S}$ & $\mathrm{S}$ & S & $\mathrm{S}$ & $\mathrm{S}$ & $\mathrm{R}$ & $\mathrm{R}$ & $\mathrm{R}$ & $\mathrm{R}$ \\
\hline
\end{tabular}

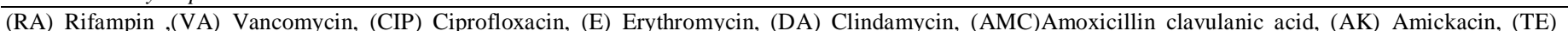

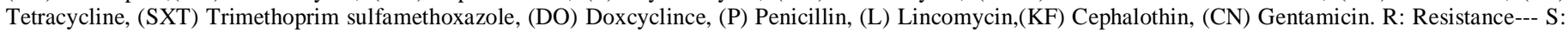




\section{RESULT AND DISCUSSION}

The three isolated strains from treated chlorinated water were analyzing the cultural, morphology and biochemical tests and comparing them with those describe in Bergey s Manual of Determination Bacteriology [23]. the isolated bacterial strains were Staphylococcus auresus, Micrococcus varians and Aeromonas hydrophila.

Regarding the determination of the resistance bacteria to different concentration of chlorine at different contact times, corresponding to the three strains tested (two gram positive and one gram negative), are shown in tables 1 .

It was verify that all three strains were sensitive to 1000 ppm and 5000 ppm for 10, 20, and 30 minutes, staphylococcus aureus and Micrococcus varians show resistant to $1 \mathrm{ppm}, 10 \mathrm{ppm}$, $50 \mathrm{ppm}$ and $100 \mathrm{ppm}$ at different times while the only gram negative bacterium, Aeromonas hydrophila is resistance to $1 \mathrm{ppm}$, $10 \mathrm{ppm}$ and 50ppm at different times and sensitive to $100 \mathrm{ppm}$ concentration at 20 minutes and 30 minutes. From above results, we suggest that those bacteria which were isolated from chlorinated water may present specific mechanisms for survival in high chlorine concentrations. In general, the Gram positive strains tested are more resistant to chlorination, i.e. their decay rates are lower for the same chlorine concentrations. the differences in behavior between Gram-positive and Gram negative strains are probably associated with differences in bacterial membrane and wall structures. Analogously differences in chlorination resistance attributable to encapsulation or concentration of nutrients in the media have been described. As it is known, either the formation or the modification processes of membrane accessory components involve protein synthesis. On the other hand, unique proteins are synthesized by bacteria as a response to stress, can enhance resistance $[24,25,26]$. In the present project we have attempted to compare sensitivity of microorganisms towards chlorine and also we have tried to determination of chlorine resistance bacteria to antibiotics. Although the strains were sensitive to a broad spectrum of antibiotic but the strains show resistant to most important clinical antibiotic such as amoxicillin, penicillin, Trimethoprim sulfamethoxazole and cephalothin, as shown in table 2, these result strongly suggest that current public health standards for drinking water based on coliform index fail to accurately predict large numbers of secondary opportunistic pathogens which these systems can sometimes harbor. Results from our experiment suggest that post chlorinated water samples bacteria are more resistant to chlorine disinfection than prechlorinated water samples. Interestingly in Khaber water works chlorine concentration used is $2 \mathrm{ppm}$ and the isolated organism are fully resistant to chlorine at this concentration. The most resistant bacterium of all isolates is Staphylococcus aureus.

\section{SIGNIFICANCE OF THE STUDY}

According to news report released by the Pacific Institute of Oakland, California, over 76 million people will perish from water related diseases by 2020 unless urgent action is not taken to improve the quality of municipal water supply. Therefore it was necessary to carry out the research study to check the quality of drinking water in the Duhok city.

This work was carried out first time in Duhok city and has revealed that the treatment given to municipal water supply is satisfactory. However some bacteria were found to resist chlorination. The resistance of these bacteria was checked however, further studies need to be done to understand the mechanism of resistance to chlorine.

\section{REFERENCES}

1. Ludovici, P. P., R. A. Phillips, and W. S. Jeter.Comparative inactivation of bacteria and viruses in tertiary- treated wastewater by chlorination, In J. D. Johnson (ed.), Disinfection: water and wastewater. Ann Arbor Science, Ann Arbor, Michigan; 1977, p. 359390.

2. LeChevallier, M. W., R. J. Seidler, and T. M. Evans.Enumeration and characterization of standard plate count bacteria in chlorinated and raw water supplies. Journal of Applied And Environmental Microbiology. 1980; 40:922-930.

3. Means, E. G., L. Hanami, H. F. Ridgway, and B. H. Olson. Enumeration of bacteria in potable water distribution systems: evaluation of media and plating techniques. Am. Water Works Assoc. Journal. 1981; 53:585-590.

4. Bishankha, S., Et Al. assessment of microbial quality of chlorinated drinking tap water and susceptibility of gram negative bacterial isolates towards chlorine. kathmandu university journal of science, engineering and technology. 2013; 9(1): 222-229.

5. Mir, J., et al.. "Resistance to chlorine of freshwater bacterial strains. Journal of Applied Microbiology. 1996; 82: 7-1 8.

6. Hiraishi, A., et al. Phenotypic and Genetic Diversity of ChlorineResistant Methylobacterium Strains Isolated from Various Environments. Journal of Applied And Environmental Microbiology. 1995; 61(6): 2099-2107.

7. Ridgway, H. F. and B. H. Olson. Chlorine Resistance Patterns of Bacteria from Two Drinking Water Distribution Systems. Journal of Applied And Environmental Microbiology. 1982; 44(4): 972-987.

8. Geldreich E. E. Microbial quality of water supply in distribution systems. CRC Press, Boca Raton, Florida ;1996.

9. Haas, C. N., and J. P. Gould. Disinfection. J. Water Pollut. Control Fed. 1979; 51:1232-1242.

10. Hoadley, A. W., and J. P. Gould. Disinfection. J. Water Pollut Control Fed. 1977; 49:1067-1073.

11. Armstrong, J. L., D. S. Shigeno, J. J. Calomiris, and R. J. Seidler. Antibiotic resistant bacteria in drinking water. Journal of Applied And Environmental Microbiology.1981;42:277-283.

12. Armstrong, J. L., J. Calomiris, and R.J. Seidler. Selection of antibiotic resistant standard plate count bacteria during water treatment Journal of Applied And Environmental Microbiology. 1982; 44:308-316.

13. Martins, S. C. S., et al. Chlorine and antibiotic-resistant bacilli isolated from an effluent treatment plant. Acta Scientiarum. 2013; 35(1): 3-9.

14. Murray, G.E.. et al. Effect of chlorination on antibiotic resistance profiles of sewage related bacteria. And Environmental Microbiology. 1984; 48(1):73-77.

15. Smith, H. W. Incidence of $\mathrm{R}^{*}$ Escherichia coli in coastal bathing waters of Britain. Nature (London). 1971; 234:155-156.

16. Strutrevant, A. B., G. H. Cassell, and T. W. Feary, Incidence of infection drug resistance among fecal coliforms isolated from raw sewage. Journal of Applied And Environmental Microbiology. 1971; 21:487-491

17. White, G. C. Handbook of chlorination for potable water. Waste water. Cooling water. Industrial processes. And swimming pools. Van Nostrand Reinhold Co. New York; 1972. 
18. Datta, N. Drug resistance and R-factors in the bowel bacteria of London patients before and after admission to hospital. British Medical Journal. 1969;2:407-411.

19. Farrar, W. E., Jr., M. Eidson, P. Guerry, S. Falkow, L. M. Drusin, and $\mathrm{R}$, B. Roberts. Interbacterial transfer of R-factor in the human intestine: in vitroaquistion of R-factor mediated kanamycin resistance by a multiresistant strain of Shigella sonnei. Journal of Infectious Diseases. 1972;126:27-33.

20. Smith, H. W. Transfer of antibiotic resistance from animal and human strains of Escherichia coli to resident E.coli in the alimentary tract of man. Lancet i.1969;1174-1176.

21. Van Graevenitz, A. The role of opportunistic bacteria in human disease. Annual Review of Microbiology. 1977; 31:447-471.

22. NCCLS-National Committee for Clinical Laboratorial Standards. Performance standards for antimicrobial susceptibility testing. Wayne: NCCLS;2005. (Supplement M100-S14).

23. Holt, J. G.; Krieg, N. R.; Sneath, P. H. A.; Staley, J. T.; Williams, S. T. Bergey's manual of determinative bacteriology. Baltimore: Williams and Wilkins; 1994.

24. Jenkins, D.E., Schultz, J.E. and Matin, A. Starvationinduced cross protection against heat or $\mathrm{H}, \mathrm{Oz}$ challenge in Escherichin coli. Journal of Bacteriology.1988; 170, 3910-3914.
25. Schultz, J.E. and Matin, A. Regulation of carbon starvation genes in Escherichia coli. In Homeostatic Mechanisms in Microorganisms. FEMS Symposium No. 44 ed. Whittenbury, R., Gould, G.W., Banks, J.G. and Board, R.G. pp. 5M6. Claver Down: Bath University Press; 1988.

26. Matin, A. and Harakeh, S. Effect of starvation on bacterial resistance to disinfectants. In Drrnkin, c If u f e rA 4icrohiolog) P. rogress and Rerent Decrlopnient.v ed. AIcFeters, G..k pp. Springer-Verlag .New York .1990; 88-103.

\section{How to cite this article:}

Mohammad I. Al-Berfkani, Anies I. Zubair, Husham Bayazed. Assessment of chlorine resistant bacteria and their susceptibility to antibiotic from water distribution system in Duhok province. $\mathbf{J}$ App Biol Biotech. 2014; 2 (06): 010-013. 